University Librafies Section

Vice Chairman and Chairman-Elect

Warren J. Haas, University of Pennsylvania, Philadelphia.

G. F. Shepherd, Jr., Cornell University Libraries, Ithaca.

\section{ANNUAL CONFERENCE PROGRAM PLANS}

At the ACRL program on Thursday, June 29, John S. Galbraith, chancellor, University of California, San Deigo, will speak on some current issues of academic libraries as seen by an administrator.

The Advisory Committee on Cooperation with Educational and Professional Organizations plans to invite a dozen organizations to send representatives to meet with the committee and other librarians for a luncheon on Monday, June 26.

The College Libraries Section program on Friday, June 30, from 2:00 to 6:00 p.m. will deal with Non-Western Resources, including a discussion by faculty members on the approaches to teaching non-western studies, with comments by libraries on library implications.

The Junior College Libraries Section and the American Association of Junior Colleges will cosponsor a conference at the University of California, Los Angeles, June 21-24, to be concerned with problems of junior college library development. Administrators and librarians are expected to participate. The ALA conference program on Friday, June 30, 12 noon-4:00 p.m. will focus on personnel needs for junior college librarians. A tour of libraries is being planned for Tuesday afternoon, June 27.

The Rare Book Section Preconference to be held at Stanford, June 22-24, will cover "techniques for special collections," including methods of disposing of duplicate or unwanted material, exhibition techniques, and valuation and appraisal.

The Subject Specialists Section program on Wednesday, June 28, 4:30 to 6:00 p.m. will be provided by the Agriculture and Biological Sciences Subsection on the National Library of Medicine's approach to information network and network structure.

The Art Subsection is planning meetings for Friday and Saturday, June 30 and July 1 . The Law and Political Science Subsection on June 30 will discuss the interests and future activities of its members.

"Trends in Budgeting for Academic Libraries" will be the subject of the UniversityLibraries Section's program on Wednesday, June 28, 8:30-10:00 p.m.
COLLEGE \&

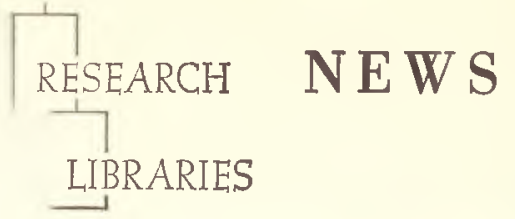

ACRL News Issue of College \& Research Libraries

Editor, David Kaser, Joint Unjversity Libraries, Nashville, Tenn. 37203.

Publications Officer, Mary Falvey, 50 E. Huron St., Chicago 60611.

ACRL Executive Secretary, George M. Bailey.

ACRL Officers, 1966/67: President, Ralph E. McCoy; College Libraries Section Chairman, Lee Sutton; Junior College Libraries Section, Harriett Genung; Rare Books Section, William H. Runge; Subject Specialists Section, Mary E. Schell; Agriculture and Biological Sciences Subsection Chairman, Roy L. Kidman; Art Subsection, Mrs. Kathryn Blackwell; Law and Political Science Subsection, Jane WiIson; Slavic and East European Subsection, Bohdan S. Wynar; University Libraries Section Chairman, John M. Dawson.

Editorial Board: Jorn M. DAwson, University of Delaware; Gustave A. Harrer, Boston University; SAMUEL RothsteIN, University of British Columbia; James E. SkIPpEr, Association of Research Libraries; Norman E. TANIS, Kansas State College of Pittsburg; Maurice F. Tauber, Columbia University; Eileen Thonnton, Oberlin College.

News from the Field, Personnel profiles and notes, classified advertising, official matter of ACRL, and other material of a timely nature is published in the News issues of College \& Research Libraries.

Inclusion of an article or advertisement in CRL does not constitute official endorsement by ACRL or ALA.

Production and Advertising and Circulation office: 50 E. Huron St., Chicago, 111, 60611. Change of address and orders for subscriptions should be addressed to College \& Research Libraries, for receipt at the above address, at least two months before the publication date of the effective issue.

Subscription to $C R L$ is included in membership dues to $A C R L$ of $\$ 6$ or more; other subscriptions to $C R L$ are $\$ 10$ per year. Neither subscriptions nor memberships include miscellaneous unscheduled supplements, which are available by purchase only. Retroactive subscriptions are not accepted. Single journal copies are available at $\$ 1.50$ each and News issues at $\$ 1.00$ each from ALA Publishing Department.

Indexed in Library Literature. Abstracted in Library Science Abstracts. Book reviews indexed in Book Review Index.

College \& Research Libraries, is the official journal of the Association of College and Research Libraries, a division of the American Library Association; and is published seventeen times per year-bi-monthly as a technical journal with II monthly News issues, combining July-August-at 1201-05 Bluff St., Fulton, Mo. 65251.

Second-class postage paid at Fulton, Mo. and at additional mailing offices. 